\title{
Recent Developments in Cross Section and Panel Count Models
}

\author{
Pravin K. Trivedi \\ Department of Economics \\ Wylie Hall \\ Indiana University \\ Bloomington, IN 47405, U.S.A \\ Email: trivedi@indiana.edu
}

\author{
Murat K. Munkin \\ Department of Economics \\ 4202 East Fowler Avenue, BSN 3426 \\ University of South Florida \\ Tampa FL 33620-5500, U.S.A. \\ Email: mmunkin@coba.usf.edu
}

January 27, 2009 


\section{References}

Bago d'Uva. T. 2005. Latent class models for use of primary care: evidence from a British panel. Health Economics. 14: 873-892

Bago d'Uva, T. 2006. Latent class models for use of health care. Health Economics. 15: 329-343.

Besag, J. 1974. Spatial interaction and the statistical analysis of lattice systems. Journal of Royal Statistical Society 36B, 192-225.

Bhat, C.R. 2001. Quasi-random maximum simulated likelihood estimation of the mixed multinomial logit model. Transportation Research: Part B, 35, 677-693.

Blundell, R., Griffith, R., and Windmeijer, F. 2002. Individual effects and dynamics in count data models. Journal of Econometrics, 102, 113-131.

Bohning, D., Kuhnert, R. 2006. Equivalence of truncated count mixture distributions and mixtures of truncated count distributions, Biometrics, 62(4), 1207-1215.

Breslow, N.E. and Clayton, D.G. 1993. Approximate inference in generalized linear mixed models. Journal of American Statistical Association, 88, 9-25.

Cameron, A.C., T. Li, Trivedi, P.K., and Zimmer, D.M. 2004. Modeling the differences in counted outcomes using bivariate copula models: with application to mismeasured counts, Econometrics Journal, 7(2), 566-584.

Cameron, A.C., and Trivedi, P.K. 1998. Regression Analysis of Count Data. New York: Cambridge University Press.

Cameron, A.C., and Trivedi, P.K. 2005. Microeconometrics: Methods and Applications. Cambridge: Cambridge University Press.

Cameron, A.C., and Trivedi, P.K. 2009. Microeconometrics Using Stata. College Station, TX: Stata Press

Cameron, A.C. and Johansson, P. 1997. Count data regressions using series expansions with applications. Journal of Applied Econometrics, 203-223

Chamberlain, G. 1992. Comment: sequential moment restrictions in panel data. Journal of Business and Economic Statistics, 10, 20-26.

Chang, F-R., and Trivedi, P.K. 2003. Economics of self-medication: theory and evidence. Health Economics, 12, 721-739.

Chib, S., Greenberg, E., and Winkelmann, R. 1998. Posterior simulation and Bayes factor in panel count data models. Journal of Econometrics, 86, 33-54.

Chib, S. and Winkelmann, R. 2001. Markov chain Monte Carlo analysis of correlated count data. Journal of Business and Economic Statistics, 19, 428-435. 
Crepon, B. and Duguet, E. 1997. Research and development, competition and innovation: pseudo-maximum likelihood and simulated maximum likelihood method applied to count data models with heterogeneity", Journal of Econometrics, 79, 355-378.

Davidson, R., and MacKinnon, J.G. 2004. Econometric Theory and Methods, Oxford: Oxford University Press.

Davis, R.A., Dunsmuir, W.T.M., Streett, S.B., 2003. Observation-driven models for Poisson counts. Biometrika 90, 777-790.

Deb, P. 2007. FMM: Stata module to estimate finite mixture models. Statistical Software Components S456895. Boston College Department of Economics.

Deb, P. 2007. FMM: Stata module to estimate finite mixture models. Statistical Software Components S456895. Boston College Department of Economics.

Deb, P., and Trivedi, P.K. 1997. Demand for medical care by the elderly: a finite mixture approach. Journal of Applied Econometrics, 12, 313-326.

Deb, P., and Trivedi, P.K. 2002. The structure of demand for medical care: latent class versus two-part models. Journal of Health Economics 21: 601-625.

Deb, P., and Trivedi, P.K. 2006a. Specification and simulated likelihood estimation of a nonnormal treatment-outcome model with selection: application to health care utilization. Econometrics Journal 9, 307-331.

Deb, P., and Trivedi, P.K. 2006b. Maximum simulated likelihood estimation of a negativebinomial regression model with multinomial endogenous treatment. Stata Journal 6: 1-10.

Deb, P., Munkin, M.K. and Trivedi, P.K. 2006a. Private insurance, selection, and the health care use: a Bayesian analysis of a Roy-type Model. Journal of Business and Economic Statistics, $24,403-415$

Deb, P., Munkin, M.K. and Trivedi, P.K. 2006b. Bayesian analysis of the two-part model with endogeneity: application to health care expenditure, Journal of Applied Econometrics, 21(6), 1081-1099, (2006.

Delgado, M.A. 1992. Semiparametric generalized least squares in the multivariate nonlinear regression model", Econometric Theory, 8, 203-222.

Demidenko, E. 2007. Poisson regression for clustered data. International Statistical Review, $75,1,96-113$.

Diggle, P., Heagerty, P., Liang, K-Y., Zeger, S. 2002. Analysis of Longitudinal Data. Oxford: Oxford University Press

El-Sayyad, G.M. 1973. Bayesian and Classical Analysis of Poisson Regression," Journal of the Royal Statistical Society. Series B (Methodological), Vol. 35, 3, 445-451 
Gouriéroux, C. and Monfort, A. 1991. Simulation based inference in models with heterogeneity. Annales d'Economie et de Statistique, 20/21, 69-107.

Gourieroux, C., and Monfort, A. 1997. Simulation Based Econometric Methods, Oxford: Oxford University Press.

Greene, W.H. 2007a. LIMDEP 9.0 Reference Guide. Plainview: Econometric Software, Inc.

Greene, W.H. 2007b. Functional form and heterogeneity in models for count data. Foundations and Trends in Econometrics, 1 (2), 113-218.

Griffith, D.A. and Haining, R. 2006. Beyond mule kicks: the Poisson distribution in geographical analysis. Geographical Analysis. 38, 123-139.

Guo, J-Q., and Trivedi, P.K. 2002. Flexible parametric distributions for long-tailed patent count distributions. Oxford Bulletin of Economics and Statistics, 64, 63-82.

Gurmu, S. and Elder, J. 2007. A simple bivariate count data regression model. Economics Bulletin, 3 (11), 1-10.

Gurmu, S., and Trivedi, P.K. 1996. Excess zeros in count models for recreational trips. Journal of Business and Economic Statistics, 14, 469-477.

Hardin, J.W., Schmiediche, H., and Carroll, R.A. 2003. Instrumental variables, bootstrapping, and generalized linear models. Stata Journal 3: 351-360.

Hausman, J. A., Hall, B.H., and Griliches, Z. 1984. Econometric Models For Count Data with an Application to the Patents - R and D Relationship. Econometrica, 52, 909-938.

Hinde, J. 1982. Compound Poisson regression models. in R. Gilchrist ed., pp. 109-121, GLIM 82: Proceedings of the International Conference on Generalized Linear Models, New York: Springer-Verlag.

Jung, R.C, Kukuk, M., Liesenfeld, R. 2006. Time series of count data: modeling, estimation and diagnostics. Computational Statistics \& Data Analysis 51, 2350 - 2364

Kaiser, M., and Cressie, N. 1997. Modeling Poisson variables with positive spatial dependence. Statistics and Probability Letters 35, 423-32.

Karlis, D. and Xekalaki, E. 1998. Minimum Hellinger distance estimation for Poisson mixtures. Computational Statistics and Data Analysis, 29, 81-103.

Kitazawa, Y. 2000. TSP procedures for count panel data estimation. Kyushu Sangyo University.

Koenker, R. 2005. Quantile Regression. New York: Cambridge University Press.

Koop, G., Poirier, D.J., and Tobias, J.L. 2007. Bayesian Econometric Methods, Volume 7 of Econometric Exercises Series, Cambridge University Press. 
Lancaster, T. 2000. The incidental parameters problem since 1948. Journal of Econometrics, 95, 391-414.

Long, J.S. and Freese, J. 2006. Regression Models for Categorical Dependent Variables Using Stata, second edition. College Station, TX: Stata Press.

Lourenco, O.D. and P.L. Ferreira. 2005. Utilization of public health centres in Portugal: effect of time costs and other determinants. Finite mixture models applied to truncated samples. Health Economics. 14: 939-953.

Lu, Z, Hui, YV, Lee, AH. 2003. Minimum Hellinger distance estimation for finite mixtures of Poisson regression models and its applications, Biometrics, 59(4. 1016-1026

MacDonald, I.L. and Zucchini, W. (1997) Hidden Markov and Other models for DiscreteValued Time Series. London: Chapman \& Hall.

Machado J., and Santos Silva, J. 2005. Quantiles for counts. Journal of American Statistical Association 100: 1226-1237.

Marshall, A.W., and Olkin, I. 1990. Multivariate distributions generated from mixtures of convolution and product families," in H. W. Block, A. R. Sampson and T. H. Savits, eds., Topics in Statistical Dependence, IMS Lecture Notes-Monograph Series, Volume 16, 371-393.

Miranda, A. 2006. QCOUNT: Stata program to fit quantile regression models for count data. Statistical Software Components S456714. Boston College Department of Economics.

Miranda, A. 2008. Planned fertility and family background: a quantile regression for counts analysis. Journal of Population Economics 21: 67-81.

Morton, R. 1987. A generalized linear model with nested strata of extra-Poisson variation. Biometrika, 74, 247-257.

Mullahy, J. 1997. Instrumental variable estimation of Poisson regression models: application to models of cigarette smoking behavior. Review of Economics and Statistics, 79, 586-93.

Munkin, M., and Trivedi, P.K. 1999. Simulated maximum likelihood estimation of multivariate mixed-Poisson regression models, with application. Econometric Journal, 1, 1-21.

Munkin, M.K. and Trivedi, P.K. 2003. Bayesian analysis of self-selection model with multiple outcomes using simulation-based estimation: an application to the demand for healthcare. Journal of Econometrics, 114, 197-220.

Munkin, M.K. and Trivedi, P.K. 2008. Bayesian analysis of the ordered Probit model with endogenous selection, Journal of Econometrics, 143, 334-348.

Munkin, M.K. and Trivedi, P.K. 2009. A Bayesian analysis of the OPES Model with a nonparametric component: application to dental insurance and dental care. Forthcoming in Advances in Econometrics, Volume 23: Bayesian Econometrics, edited by Siddhartha Chib, Gary Koop, and 
Bill Griffiths. Elsevier Press.

Nelsen, 2006. An Introduction to Copulas Second edition. New York: Springer

Newey, W. 1987. Efficient estimation of limited dependent variable models with endogenous explanatory variables. Journal of Econometrics 36: 231-250.

Pitt, M., Chan, D., Kohn, R. 2006. Efficient Bayesian inference for Gaussian copula regression. Biometrika, 93, 537-554.

Rabe-Hesketh, S., Skrondal A., Pickles, A. 2002. Reliable estimation of generalized linear mixed models using adaptive quadrature. Stata Journal, 2, 1-21.

Romeu A. 2004. ExpEnd: Gauss code for panel count data models. Journal of Applied Econometrics 19, 429-434.

Skrondal, A. and Rabe-Hesketh, S. 2004. Generalized Latent Variable Modeling: Multilevel, Longitudinal and Structural equation Models. London: Chapman \& Hall.

Terza, J. 1998. Estimating count data models with endogenous switching: sample selection and endogenous switching effects. Journal of Econometrics, 84, 129-139.

Train, K. 2002. Discrete Choice Methods with Simulation. New York: Cambridge University Press.

Trivedi, P.K. and Zimmer, D.M. 2007. Copula modeling: an introduction for practitioners. Foundations and Trends in Econometrics, 1(1), 1-110.

Vuong, Q. 1989. Likelihood ratio tests for model selection and non-nested hypotheses. Econometrica, 57, 307-333.

Wang, K; Yau, KKW; Lee, AH. 2002. A hierarchical Poisson mixture regression model to analyze maternity length of hospital stay Statistics in Medicine, 21, 3639-3654.

Windmeijer, F. and Santos Silva, J.M.C. 1997. Endogeneity in count data models. Journal of Applied Econometrics, 12, 281-294.

Windmeijer, F. 2008. GMM for panel count data models. Advanced Studies in Theoretical and Applied Econometrics, 46, 603-624.

Winkelmann, R. 2005. Econometric Analysis of Count Data 5th edition, Berlin, SpringerVerlag.

Wooldridge, J.M. 1997. Multiplicative panel data models without the strict exogeneity assumption. Econometric Theory, 13, 667-678.

Wooldridge, J.M. 1999. Distribution-free estimation of some nonlinear panel data models. Journal of Econometrics 90, 77-97.

Wooldridge, J.M. 2002. Econometric Analysis of Cross Section and Panel Data, 2001. Cambridge, MIT Press. 
Xiang, L.; Yau, K. K.W.; Van Hui, Y.; Lee, A. H.; 2008. Minimum Hellinger distance estimation for k-Component Poisson mixture with random effects, Biometrics 64(2), 508-518.

Zimmer, D.M. and Trivedi, P.K. 2006. Using trivariate copulas to model sample selection and treatment effects: application to family health care demand, Journal of Business and Economic Statistics, 24(1), 63-76. 